\title{
DEVELOPMENT OF THE RELATED ANEMIC SYNDROME IN VARIOUS TYPES OF ENDOCRINE PATHOLOGY (literature review) ${ }^{*}$
}

\author{
N. E. Piriatinska ${ }^{1,2}$, V. Yu. Vdovichenco ${ }^{2}$, V. B. Bakuridze-Manina ${ }^{3}$, \\ O. B. Nekhanevych ${ }^{3}$, N. O. Yurevych ${ }^{2}$, O. O. Trach ${ }^{2}$, L. V. Saprichova ${ }^{1}$, K. M. Zolotko \\ ${ }^{1}$ V.N. Karazin Kharkiv National University, Kharkiv, Ukraine; \\ ${ }^{2}$ Kharkiv National Medical University, Kharkiv, Ukraine; \\ ${ }^{3}$ State Institution "Dnipropetrousk Medical Academy of the Ministry of Health of Ukraine», \\ Dnipro, Ukraine; \\ ${ }^{4}$ Institute for Problems of Cryobiology and Cryomedicine \\ of the National Academy of Sciences of Ukraine, Kharkiv, Ukraine \\ natalia_piryatinskaya@ukr.net
}

Anemia is a global public health problem not only in developing countries, but also in countries with a high standard of living, adversely affecting human health and creating serious negative social-economic consequences. According to the WHO, 1.62 billion people are affected by anemia in the world, which almost corresponds to $25 \%$ of the population. Anemia can occur in any period of a human's lifetime $[1,2]$.

Anemia is a group of clinical and hematological syndromes characterized by a decrease in the number of red blood cells and the concentration of hemoglobin in the blood in accordance with WHO recommendations below $120 \mathrm{~g} / \mathrm{l}$ for women and less than $130 \mathrm{~g} / \mathrm{l}$ for men. For men - the number of red blood cells is less than $4.0 \mathrm{million} / \mathrm{\mu l}$, for women - the number of red blood cells is less than 3.8 million/pl [3].
There is currently no global unified classification of anemia. Classification features are the morphology of red blood cells, the severity of anemia, the regenerative activity of bone marrow, the type of erythropoiesis, the leading pathogenetic mechanism of the occurrence of anemia. Classification of anemia depending of mechanical reasons is based on one of three factors, or on its combinations: blood loss, insufficient formation of red blood cells or its increased destruction. In clinical practice, the separation of anemia is widely used according to the hemoglobin content in red blood cells (hypochromic, normochromic and hyperchromic anemia) and the volume of red blood cells (microcyte, normocyte, and macrocyte) [1,4].

Anemia is very diverse in etiology, pathogenesis and clinical and hematological signs and most often accompanies the course of vari-

* The authors assume responsibility for the published work.

The authors guarantee absence of competing interests and their own financial interest when carrying out the research and writing the article.

The manuscript was received by the editorial staff 22.11.2020. 
ous diseases of the endocrine system, while being usually one of the manifestations of a chronic disease, and not an independent pathology $[5,6]$. Anemia has a negative impact on the quality of life of patients, this is a risk of concomitant pathology and, in some cases, death [7-10].

The process of hematopoiesis is still not well understood; it is multifaceted, it includes a huge number of different elements, from vitamins and minerals to hormones. Erythropoiesis is stimulated by catecholamines, glucocorticoids, androgens, thyroid hormones, insulin, placental prolactin, IL-3, IL-6, IL-9, IL-11, $\mathrm{CSF}$, folic acid, vitamins $\mathrm{C}, \mathrm{B}_{12}$, and iron-containing drugs $[11,12]$.

The main humoral factor-hormone that regulates erythropoiesis is erythropoietin, it is synthesized primarily by the kidneys $[13,14]$. Reducing the formation of erythropoietin occurs with increased tissue oxygenation, as well as under the influence of estrogens, glucagon, acetylcholine, interferons, TNF-a, IL-1, IL-5, erythrocyte keillons [10, 11]. The synthesis of erythropoietin is directly or indirectly affected by hormones of the endocrine glands, therefore, with their dysfunction, changes in red blood parameters can be observed. The pathophysiological basis of anemia observed in endocrine disorders can be multifactorial and, therefore, not always clear [10, 19]. The presence of endocrine pathology is often a mechanism for the development of various types of anemia, and anemia, in turn, aggravates the course of a chronic disease [15-18].

\section{Thyroid Disorders}

Impaired thyroid function can lead to different types of anemia. In patients with hyperthyroidism, an increase in bone marrow erythropoietic activity is observed. This is due to the increased tissue oxygen demand associated with thyrotoxicosis, as the response to this increases the production of erythropoietin [10]. However, thyroid hormones also have a direct effect on erythropoiesis, possibly through catecholamine receptors. Since with thyrotoxicosis the volume of blood plasma and the number of erythrocytes increase simultaneously, the hematocrit does not change, although anemia is observed in $10-25 \%$ of patients [11].
In some cases, microcytic hypochromic anemia develops, and in 1-3\% pernicious anemia [20]. Numerous studies confirm the close relationship between changes in bone marrow function and thyroid immune disorders. With hyperthyroidism, moderate macrocytic normochromic anemia is often observed, and $20-60 \%$ of patients with chronic autoimmune thyroiditis develop true pernicious anemia. Also, in some cases, hyperthyroidism can be observed in addition to erythrocytosis, moderate lymphocytosis, moderate granulocytopenia and thrombocytopenia $[21,22]$.

In some patients, anemia is associated with a deficiency of iron, folate and vitamin $\mathrm{B}_{12}$, accompanied by corresponding changes in the morphology of red blood cells. In other patients, anemia is of a normochromic normocytic nature and, apparently, is associated with thyrotoxicosis proper. Erythropoiesis is ineffective. It is possible that in some cases the development of anemia is associated with hemodilution. Cases of sideroblastic anemia with thyrotoxicosis are described. Lima et al. in his studies of cases of severe pancytopenia in the group of patients with thyrotoxicosis, he concludes that thyroid function should be evaluated in patients with pancytopenia even in the absence of symptoms of endocrine pathology [22]. Treatment is carried out for the underlying disease, if a deficiency of iron, vitamin $\mathrm{B}_{12}$ and folic acid is confirmed by laboratory tests, then appropriate treatment is prescribed.

With hypothyroidism, anemia is observed in $60 \%$ of patients, there is a decrease in erythropoiesis and hematocrit [23]. By its nature, anemia can be hypochromic microcytic, normochromic normocytic, and macrocytic, the severity of which varies depending on the degree of hypothyroidism [21]. Anemia may not be detected (masked) due to a decrease in the patient's blood plasma volume. Macrocytosis is found in $55 \%$ of patients with hypothyroidism and can develop without nutritional deficiencies [24]. A number of patients have acanthocytes. The causes of anemia are mixed. Normochromic normocytic anemia is most often observed, which is caused by a deficiency of thyroid hormone proper [25].

With thyroid hypofunction, a decrease in the acidity of the stomach due to a decrease in 
the number of parietal cells is noted, and as a result, a decrease in the synthesis of hydrochloric acid and a deterioration in the absorption of iron due to the inability to turn into an assimilable form.

Hypochromic microcytic anemia develops. Parietal cells are also responsible for the synthesis of glycoprotein associated with $\mathrm{B}_{12}$. As a result, the absorption of $\mathrm{B}_{12}$ and folic acid may be impaired, since both substances are distributed throughout the body, absorbed in the intestine [23, 26, 27].

If a chronic iron deficiency has arisen in the body for any reason, the deiodinase enzyme may be blocked. This enzyme promotes the conversion of the $\mathrm{T}_{4}$ hormone into the active thyroid hormone $\mathrm{T}_{3}$. A decrease in $\mathrm{T}_{3}$ leads to a decrease in the activity of thyroid hormones and causes symptoms of hypothyroidism. In addition, if the iron in the thyroid gland is deficient, then the activity of thyroperoxidase, an enzyme that is directly involved in the synthesis of thyroid hormones and is iron-dependent, decreases $[23,26]$.

As you can see, iron significantly affects the functioning of the thyroid gland, disturbances in the functioning of which, in turn, can significantly affect the intake of iron in the body. In case of anemia or impaired iron metabolism, one should not forget about the state of the thyroid gland. Thus, hypothyroidism per se contributes to macrocytosis of red blood cells. Thyroid hormone replacement therapy corrects the hematocrit and eliminates macrocytosis within 3-6 months after the start of treatment. The purpose of iron, vitamin $\mathrm{B}_{12}$, folate preparations without thyroid hormone preparations is ineffective.

\section{Disorders of the parathyroid glands}

In hyperparathyroidism, anemia is relatively rare only in severe cases of the disease, when there are signs of bone resorption, the blood levels of $\mathrm{Ca}^{2+}$ and parathyroid hormone, alkaline phosphatase activity are very high [28]. Parathyroid hormone inhibits the proliferation of erythroid germ cells by suppressing erythropoietin receptors on erythroid progenitor cells in the bone marrow. As a result, normocytic and normochromic anemia occurs. In primary hyperparathyroidism, this effect is observed at very high concentrations of parathyroid hormone. In secondary severe hyperparathyroidism with chronic renal failure, this effect is more pronounced, since the synthesis of erythropoietin is impaired. This is usually associated with a partial replacement of the cellular components of the bone marrow with fibrous tissue [29-31].

Decreased parathyroid function alone does not cause anemia, but with immunological forms of hypoparathyroidism in combination with other endocrine disorders, megaloblastic anemia and erythroblastopenia can be observed [10, 32].

\section{Diabetes}

Diabetes mellitus along with serum creatinine level is one of the main reasons for the development of renal anemia of varying severity [33]. If there are signs of diabetic nephropathy, such as albuminuria and/or decreased kidney function, the risk of anemia increases significantly. Studies have shown that in $60 \%$ of patients with anemia diagnosed on the basis of WHO criteria, a decrease in glomerular filtration rate was determined [34]. As kidney function worsens, the incidence of anemia increases regardless of gender. Hemoglobin concentration is most closely related to glomerular filtration rate, including in patients with normal serum creatinine. The results show that damage to interstitial cells or disruption of the interaction between tubules, peritubular fibroblasts and endothelium, necessary for normal hematopoiesis, contribute to impaired erythropoietin secretion [34]. Some authors propose to consider the production of this hormone as a marker of the severity of tubulointerstitial changes in diabetes mellitus [35]. In addition to damage to tubulointerstitial cells, anemia can also be caused by disturbances in the feedback mechanisms between tissue oxygenation, erythropoietin, and hemoglobin [34]. This is supported by the preservation of the response to acute hypoxia in patients with diabetes mellitus and anemia [36].

An inverse relationship was observed between the content of erythropoietin and hemoglobin in healthy people. In non-renal anemia, enhanced erythropoiesis is noted due to a com- 
pensatory increase in erythropoietin secretion. At the same time, in patients with renal anemia, erythropoietin levels remain normal, reflecting its relative deficiency [37]. Some authors have revealed a negative correlation between the concentration of erythropoietin and the level of glycated hemoglobin and suggested that a decrease in the secretion of erythropoietin may be a result of an increase in the level of glycated hemoglobin [38].

Anemia in diabetic nephropathy is usually more severe and develops faster than in patients with other types of diseases. For example, according to the NHANES III epidemiological study conducted in the USA, the frequency of anemia in patients with chronic renal failure and diabetes was 2 times higher than in patients with a comparable impaired renal function who did not suffer from diabetes [39].

During of a simultaneous epidemiological study by S.A. Martynov et al. [40] with the inclusion of 2015 patients with type 1 diabetes and type 2 diabetes found that a significant increase in the number of patients with anemia in type 1 diabetes was observed at the 2nd stage of chronic kidney disease, i.e. with the onset of an initial decrease in renal filtration function (glomerular filtration rate $<90 \mathrm{ml} / \mathrm{min} / 1.73 \mathrm{~m}^{2}$ ), and with T2DM - at the 3rd stage of chronic kidney disease, i.e. since the formation of chronic renal failure (glomerular filtration rate $<60 \mathrm{ml} / \mathrm{min} / 1.73 \mathrm{~m}^{2}$ ). As chronic kidney disease progresses, the frequency of anemia increases to $80 \%$. The severity of anemia is influenced by the level of decrease in glomerular filtration rate and the severity of albuminuria.

Anemia is an underestimated risk factor. Causing tissue hypoxia, it promotes mitogenic and fibrogenic changes, and also modifies the expression of genes that regulate capillary angiogenesis and permeability, vasomotor response, glycolysis, cell apoptosis, etc. [41]. In addition, anemia activates the sympathetic and renin-angiotensin systems, which contribute to the development of proteinuria and hypertension in patients with chronic nephropathy [42]. The earlier detection and correction of anemia can lead to a reduced risk of cardiovascular complications in patients with diabetic nephropathy.

\section{Disorders of the gonads}

The relationship between androgens and erythropoiesis has been known for decades. Androgens stimulate the hematopoietic system through various mechanisms. These include stimulation of erythropoietin, increased bone marrow activity, including the incorporation of iron into red blood cells [43]. The insufficiency of the function of the gonads is accompanied by a decrease in the production of androgens. This leads to a decrease in $\mathrm{Hb}$ content by $10-20 \mathrm{~g} / \mathrm{l}$ in combination with macrocytosis. With excessive androgen production in patients, erythrocytosis is observed [44]. Men produce 3 times more erythropoietin than women. These differences depend on the stimulating effect of androgens on erythropoiesis, the direct effect of androgens on CFU-E, and estrogen inhibition [45]. Therefore, the concentration of hemoglobin in men is 10-30 g/l higher than in women. Castration and exogenous estrogens lead to a change in hemoglobin in men. After puberty, the number of red blood cells increases by about 10-13\%. By the age of 60, the concentration of hemoglobin in men and women becomes the same. With testosterone treatment, hemoglobin levels can be restored. [7, 45, 46].

\section{Disorders of the pituitary and hypothalamus}

With insufficient function of the anterior pituitary gland, moderate normochromic normocytic anemia or anemia with slight macrocytosis and sometimes leukopenia can be observed. The morphology of red blood cells is not changed. Anemia with hypopituitarism is secondary due to a deficiency of hormones that are secreted and controlled by the pituitary gland: thyroid, adrenal, androgens. Deficiency of hormones, such as growth hormones and prolactin, can cause anemia as with hypothyroidism. Hypopituitarism inhibits erythropoiesis due to changes in tissue oxygen consumption. This leads to a decrease in the production of erythropoietin, a decrease in the mass of red blood cells. With insufficiency of the anterior pituitary, reticulocytopenia is noted with a pronounced decrease in the number of erythroid germ cells in the bone marrow. With this disease, the life expectancy of red blood cells is shortened, there are signs of ineffective eryth- 
ropoiesis. Growth hormone treatment normalizes red blood counts [47-50].

Hypothalamic function insufficiency is manifested by moderate normocytic and normochromic anemia. With iron or vitamin $\mathrm{B}_{12} /$ folic acid deficiency, microcytic or macrocytic anemia may develop [51]. Anemia in case of dysfunction of the hypothalamus is manifested as a result of the insufficiency of those hormones that it has affected (adrenal or androgen insufficiency, hypothyroidism) [52, 53].

\section{Disorders of the adrenal glands}

In chronic adrenal insufficiency (Addison's disease), a decrease in the mass of red blood cells is observed, but it is masked by a decrease in blood plasma volume and dehydration. In untreated patients, the average hemoglobin level is about $130 \mathrm{~g} / \mathrm{l}$. After correction of dehydration, normochromic normocytic anemia is revealed. The hemoglobin concentration decreases to $80 \%$ of the level determined before treatment. As treatment continues, the number of red blood cells in the blood normalizes. Sometimes anemia can take the features of megaloblastic. The mechanism of anemia is not known [10, 19, 54].

Addison's disease can be accompanied by pernicious anemia, in which case the anemia can be macrocytic with megaloblastic changes in the bone marrow. Serum iron levels are normal, but erythrocyte iron utilization is slightly reduced. The mechanism for the development of anemia is unclear, but adrenalectomy always leads to hypoplasia of erythrocyte progenitors in the bone marrow. Apparently, cortisol indirectly affects the rate of erythropoiesis, since the introduction of this substance causes an increase in oxygen consumption and subsequent stimulation of erythropoietin production. Secondary and tertiary chronic insufficiency of the adrenal cortex occurs with damage to the pituitary or hypothalamus and, as a rule, is accompanied by multiple hormonal insufficiency $[10,19,54,55]$.

Conclusions. Summarizing the literature data, it can be summarized that an increase or decrease in the function of individual endocrine glands leads to a disruption in the formation of erythropoietin, impaired absorption of iron, folic acid and vitamin $\mathrm{B}_{12}$ and, as a result, ineffective erythropoiesis. As a result, the resulting anemia can worsen the course of the underlying disease, and its treatment is often effective only in conjunction with the adjustment of hormonal status. These features must be taken into account in clinical practice in the management of patients with various endocrine pathologies.

\section{REFERENCES}

1. https://www.who.int.

2. The global prevalence of anaemia in 2011, Geneva, 2015: $43 \mathrm{p}$.

3. Haemoglobin concentrations for the diagnosis of anaemia and assessment of severity, Geneva, 2011: 6 p.

4. Kim SH, Lilot M, Murphy LS, et al. Anesth Analg 2014; 119(2): 332-346. doi: 10.1213/ANE.0000000000000272.

5. Harper JW, Holleran SF, Ramakrishnan R, et al. Am J Hematol 2007; 82(11): 996-1000. DOI:10.1002/ ajh.20996.

6. Chaparro CM, Suchdev PS. Ann NY Acad Sci 2019; 1450(1): 15-31. doi: 10.1111/nyas.14092.

7. Roy CN, Snyder PJ, Stephens-Shields AJ, et al. JAMA Intern Med 2017; 177(4): 480-490. doi: 10.1001/jamainternmed.2016.9540.

8. Patel MS, McKie E, Steiner MC, et al. BMJ Open Resp Res 2019; 6: e000454. doi: 10.1136/bmjresp-2019-000454.

9. Nutritional anaemias: tools for effective prevention and control, Geneva, 2017: 96 p.
10. Provan D, Baglin T, Dokal I, Johannes de Vos. Oxford Handbook of Clinical Haematology, Oxford Univ Press, 2015: 864 p.

11. McPherson RA, Pincus MR. Henry's clinical diagnosis and management by laboratory methods, Saunders, 2011: 1568 p.

12. Chasis JA. Curr Opin Hematol 2006; 13(3): 137-141. doi: 10.1182/blood-2008-03-077883.

13. Pan X, Suzuki N, Hirano I, et al. PLoS ONE 2011; 6(10): e25839. doi: 10.1371/journal.pone.0025839.

14. Shih HM, Wu CJ, Lin SL. J Formos Med Assoc 2018; 117(11): 955-963. doi: 10.1016/j.jfma.2018.03.017.

15. Haase VH. Blood Rev 2013;27(1):. 41-53. doi: 10.1016/j. blre.2012.12.003.

16. Donnelly S. Am J Kidney Dis 2001; 38: 415-425. doi: 10.1053/ajkd.2001.26111.

17. Tumburu L, Thein SL. Curr Opin Hematol 2017; 24(3): 173-182.

18. Barminko J, Reinholt B, Baron MH. Dev Comp Immunol 2016; 58: 18-29. doi: 10.1016/j.dci.2015.12.012. 
19. Singh AK, Williams GH. Textbook of nephro-endocrinology, Academic Press, 2018: 584.

20. Floriani C, Feller M, Aubert CE, et al. Thyroid 2018; 28(5): 575-582. doi.org/10.1089/thy.2017.0480.

21. Mehmet E, Aybike K, Ganidagli S, Mustafa K. Endocrine J 2012; 59(3): 213-220. doi: 10.1507/endocrj.ej11-0096.

22. Lima CSP, Zantut Wittmann DE, Castro V, et al. Thyroid 2006; 16(4): 403-409. doi: 10.1089/thy.2006.16.403.

23. Szczepanek-Parulska E, Hernik A, Ruchała M. Pol Arch Intern Med 2017; 127(5): 352-360. doi: 10.20452/ pamw.3985.

24. Nagao T, Hirokawa M. J Gen Fam Med 2017; 18: 200 204. doi: $10.1002 /$ jgf2.31.

25. Patel RP, Jain A. Thyroid Res Pract 2017; 14: 22-24 doi: 10.4103/0973-0354.200564.

26. Chanchal Das, Pranab K. Sahana, Nilanjan Sengupta, et al. Indian J Endocrinol Metab 2012; 16(8): 361-363.

27. McLean E, de Benoist B, Allen LH. Food Nutr Bull 2008; 29(2): 38-51. doi: 10.1177/15648265080292S107.

28. Motoko Tanaka, Hirotaka Komaba, Masafumi Fukagawa. Therapeutic Apheresis Dial 2018; 22(3): 242-245. doi: 10.1111/1744-9987.12685.

29. Sikole A. Med Hypotheses 2000; 54(2): 236-238. doi: 10.1054/mehy.1999.0027.

30. Gallieni M, Corsi C, Brancaccio D. Am J Nephrol 2000; 20(2): 89-96. doi: 10.1159/000013563.

31. Satyendra Kumar Sonkar, Harendra Pratap Singh, Gyanendra Kumar Sonkar, Sant Pandey. J Family Med Prim Care 2018; 7(4): 815-818. doi: 10.4103/jfmpc.jfmpc_174_17.

32. Memon I, Norris KC, Bomback AS, et al. Cardiorenal Med 2013; 3(2): 120-127. doi: 10.1159/000351229.

33. Dachi RA, Awwalu S, Waziri AD, et al. West Afr J Med 2019; 36(2): 133-137.

34. Thomas MC, Cooper ME, Rossing K, Parving HH. Diabetologia 2006; 49(6): 1151-1157. doi: 10.1007/s00125006-0254-z.

35. Idris I, Tohid H, Muhammad NA, et al. BMJ Open 2018; 8(12): 9. doi: 10.1136/bmjopen-2018-025125.

36. Bosman D, Osborne C, Marsden J, et al. Diabet Med 2002; 19(1): 65-69. doi: 10.1046/j.1464-5491.2002.00634.x.
37. Thomas M, Cooper M, Tsalamandris C, et al. Arch Intern Med 2005; 165(4):466-469. doi: 10.1001/archinte. 165.4.466.

38. Symeonidis A, Kouraklis-Symeonidis A, Psiroyiannis A, et al. Ann Hematol. 2006; 85(2): 79-85. doi: 10.1007/ s00277-005-1102-9.

39. Astor B, Muntner P, Levin A, et al. Arch Intern Med 2002; 162(12): 1401-1408. doi: 10.1001/archinte.162.12.1401.

40. Martynov SA, Shestakova MV, Shilov EM, et al. Saharnyj Diabet 2017; 20(5): 318-328.

41. Deicher R, Hörl WH. Curr Opin Nephrol Hypertens 2003; 12(2): 139-143. doi: 10.1097/00041552-200303000-00003.

42. Fine L, Bandyopadhay D, Norman J. Kidney Int Suppl 2000; 57: 22-26. doi: https://doi.org/10.1046/j.1523-1755. 2000.07512.x.

43. Shahani S, Braga-Basaria M, Maggio M, Basaria S. J Endocrinol Invest 2009; 32(8): 704-716.

44. Ferrucci L, Maggio M, Bandinelli S, et al. Arch Intern Med 2006; 166(13): 1380-1388.

45. Delev D, Rangelov A, Ubenova D, et al. Int $J$ Pharm Clin Res 2016; 8(11): 1489-1492.

46. Maggio M, Ceda GP, Lauretani F, et al. The Aging Mal 2011; 14(1): 42-47. doi: 10.3109/13685538.2010.518179.

47. Ellegala DB, Alden TD, Couture DE, et al. J Neurosurg 2003; 98(5): 974-977. doi: 10.3171/jns.2003.98.5.0974.

48. Laway BA. Austin J End Diabetes 2014; 1(4): 1020.

49. Nishioka H, Haraoka J. J Endocrin Invest 2005; 28(6): 528-533. doi: 10.1007/bf03347241.

50. Lang D, Mead JS, Syke DB. J Gen Intern Med 2015; 30(5): 692-696. doi: 10.1007/s11606-014-3161-x.

51. Beck W, Stubbe P, Tillmann W. Eur J Pediatr 1980; 135(1): 103-105.

52. Hamilton WF. Textbook of Human Physiology, Literary Licensing, 2013: 640 p.

53. Petryk A, Shankar RK, Giri N. J Clin Endocrinol Metab 2015; 100(3): 803-811. doi: 10.1210/jc.2014-4357.

54. Hsu B, MUdden M, CLynch E. Am J Med Sci 1997; 314(1): 41-43. doi: 10.1097/00000441-199707000-00009.

55. O’Grady MJ, Monavari AA, Cotter M, Murphy NP. BMJ Case Rep 2015; 2015. doi: 10.1136/bcr-2014-208514. 


\section{DEVELOPMENT OF THE RELATED ANEMIC SYNDROME IN VARIOUS TYPES OF ENDOCRINE PATHOLOGY (literature review)}

N. E. Piriatinska ${ }^{1,2}$, V. Yu. Vdovichenco ${ }^{2}$, V. B. Bakuridze-Manina ${ }^{3}$, O. B. Nekhanevych ${ }^{3}$, N. O. Yurevych ${ }^{2}$, O. O. Trach ${ }^{2}$, L. V. Saprichova ${ }^{1}$, K. M. Zolotko ${ }^{4}$

${ }^{1}$ V.N. Karazin Kharkiv National University, Kharkiv, Ukraine;

${ }^{2}$ Kharkiv National Medical University, Kharkiv, Ukraine;

${ }^{3}$ State Institution "Dnipropetrovsk Medical Academy of the Ministry of Health of Ukraine», Dnipro, Ukraine;

${ }^{4}$ Institute for Problems of Cryobiology and Cryomedicine of the National Academy of Sciences of Ukraine, Kharkiv, Ukraine natalia_piryatinskaya@ukr.net

Anemia is a public health problem in almost all countries in the world, negatively affects human health, affects all sectors of the population and creates serious negative socio-economic consequences. The fact of anemia is the basis for stating a pathological condition that requires a nosological diagnosis with the identification of the causes of anemia. The article presents a review of modern literature, covering the impact of endocrine pathology on the development of various types of anemia in humans. The importance of biologically active substances in normal erythropoiesis is described, the role of erythropoietin and the action of hormones of the endocrine glands on its formation are considered. Endocrine pathologies such as hypo- and hyperthyroidism, hypo- and hyperparathyroidism, diabetes mellitus, insufficiency of the pituitary, hypothalamus, sex glands, adrenal glands and features of the development of anemic conditions are discussed. An analysis of the literature showed that an increase or decrease in the function of individual endocrine glands leads to a disruption in the formation of erythropoietin, impaired absorption of iron, folic acid and vitamin $\mathrm{B}_{12}$ and, as a result, ineffective erythropoiesis. Anemia negatively affects the course of the underlying disease, significantly worsening its prognosis, and its treatment is more often effective only in conjunction with the adjustment of hormonal status. Despite significant progress in the study of the pathogenesis of anemia, the emergence of new scientific data on the issues and mechanisms of regulation of erythropoiesis, classification options for anemia are still being discussed, the criteria for diagnosing a number of anemias and its combination with chronic diseases of endocrine and non-endocrine nature are being reviewed.

Key words: anemia, erythropoiesis, erythropoietin, endocrine pathologies.

\section{РОЗВИТОК СУПУТНЬОГО АНЕМІЧНОГО СИНДРОМУ ПРИ РІЗНИХ ВИДАХ ЕНДОКРИННОЇ ПАТОЛОГІЇ (огляд літератури)}

Пірятінська Н. Є., ${ }^{1,2}$ Вдовіченко В. Ю. ${ }^{2}$, Бакурідзе-Маніна В. Б. ${ }^{3}$, Неханевич О. Б. ${ }^{3}$, Юревич Н. О. ${ }^{2}$, Трач О. О. ${ }^{2}$, Сапричова Л. В. ${ }^{1}$, Золотько К. М. ${ }^{4}$

${ }^{1}$ Харківський національний університет імені В.Н. Каразіна, м. Харків, Україна;

${ }^{2}$ Харківський національний медичний університет, м. Харків, Украӥна;

${ }^{3}$ Державний заклад "Дніпропетровська медична академія

Міністерства охорони здоров'я Украӥни» м. Дніпро, Украйна;

${ }^{4}$ Інститут проблем кріобіології і кріомедицини НАН України, м. Харків, Украӥна natalia_piryatinskaya@ukr.net

У статті представлений огляд сучасної літератури, що висвітлюе питання впливу ендокринної патології на розвиток різних видів анемій у людини. Описуеться значення біологічно активних речовин в нормальному еритропоезі, розглядаеться роль еритропоетину і дію гормонів ендокринних залоз на його розвиток. Обговорюються такі ендокринні патології, як гіпо- та гіпертиреоїдизм, гіпо- та гіперпаратиреоїдизм, цукровий діабет, недостатність функції гіпофіза, гіпоталамуса, статевих залоз, наднирників і особливості розвитку анемічних станів при них. Аналіз літератури показав, що анемія негативно впливає на перебіг основного захворювання, істотно погіршуючи його прогноз, а її лікування частіше ефективно тільки спільно з коригуванням гормонального статусу.

К л юч ові слов а : анемія, ерітропоез, еритропоетин, ендокринні патології. 


\section{РАЗВИТИЕ СОПУТСТВУЮЩЕГО АНЕМИЧЕСКОГО СИНДРОМА ПРИ РАЗЛИЧНЫХ ВИДАХ ЭНДОКРИННОЙ ПАТОЛОГИИ (обзор литературы)}

Пирятинская Н. Е., ${ }^{1,2}$, Вдовиченко В. Ю. ${ }^{2}$, Бакуридзе-Манина В. Б. ${ }^{3}$, Неханевич О. Б. ${ }^{3}$, Юревич Н. А. ${ }^{2}$, Трач О. А. ${ }^{2}$, Сапричева Л. В. ${ }^{1}$, Золотько К. Н. ${ }^{4}$

${ }^{1}$ Харьковский национальный университет илени В. Н. Каразина, г. Харьков;

${ }^{2}$ Харьковский национальный медицинский университет, г. Харьков, Украина; ${ }^{3}$ Государственное учреждение "Днепропетровская медицинская академия Министерства здравоохранения Украиныл", г. Днепр, Украина;

${ }^{4}$ Институт проблем криобиологии и криоледицины НАН Украины, г. Харьков, Украина natalia_piryatinskaya@ukr.net

В статье представлен обзор современной литературы, освещающей механизмы влияния эндокринной патологии на развитие различных видов анемий у человека. Описывается значение биологически активных веществ в нормальном эритропоэзе, рассматривается роль эритропоэтина и действие гормонов эндокринных желез на его образование. Обсуждаются такие эндокринные патологии, как гипо- и гипертиреоидизм, гипо- и гиперпаратиреоидизм, сахарный диабет, недостаточность функции гипофиза, гипоталамуса, половых желез, надпочечников и особенности развития анемических состояний при них. Анализ литературы показал, что анемия отрицательно влияет на течение основного заболевания, существенно ухудшая его прогноз, а ее лечение чаще эффективно только совместно с корректировкой гормонального статуса.

К люче вы е слов в : анемия, эритропоэз, эритропоэтин, эндокринная патология. 